\title{
Offshoring - proces relokacji funkcji firmy Typy i czynniki
}

https://doi.org/10.33141/po.2005.11.07

Przegląd Organizacji, Nr 11 (790), 2005, ss. 26-28 www.przegladorganizacji.pl

Katarzyna Zakrzewska Towarzystwo Naukowe Organizacji i Kierownictwa (TNOiK)

\section{Motywy offshoringu}

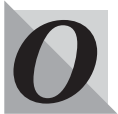

ffshoring jest definiowany jako przeniesienie wydzielonych wcześniej funkcji firmy do innych firm, znajdujących się w krajach charakteryzujących się przede wszystkim niskimi kosztami pracy ${ }^{1}$. Jednak takie ujęcie nie odzwierciedla w pełni zagadnienia offshoringu, ponieważ poza obniżeniem kosztów pracy, a to jest główny motyw przenoszenia operacji firmy, występują także i inne, takie jak: redukcja innych kosztów, poprawa jakości usług, koncentracja na kluczowych kompetencjach, przyspieszenie procesów biznesowych itp. ${ }^{2)}$ Krajami, które w 2001 r. stanowiły główne lokalizacje dla offshoringu były: Irlandia, Indie, Kanada, Izrael, Chiny, Meksyk, Polska, Rumunia, Węgry, Czechy, Australia, Filipiny, Rosja, Tajlandia, Republika Południowej Afryki. Indie, Chiny, kraje Europy Wschodniej i Filipiny charakteryzują się natomiast największą dynamika wzrostu eksportu tego typu usługis. Do krajów tych przenoszone są np. przetwarzanie danych, tzw. call centers, księgowość, płace, obsługa informatyczna, wsparcie techniczne, ale również procesy wymagające udziału wysoko wykształconych kadr, jak: zarządzanie ryzykiem, analizy finansowe, badania i rozwój.

\section{Typy i definicje relokacji funkcji firmy}

W

literaturze ekonomicznej nie ma zgodności co do terminologii procesów związanych z relokacją funkcji firmy do innych krajów, gdyż dla pojęcia offshoring pojawiło się wiele, niekiedy wzajemnie sprzecznych definicji dotyczących np. procesu relokacji funkcji firmy w odniesieniu do krajów położonych na tym samym lub innym kontynencie, jak i w przypadku zlecania usług do wykonania podmiotowi trzeciemu oraz gdy funkcje te wykonuje filia znajdująca się w jednej z tych lokalizacji.

Tab. Typy offshoringu

\begin{tabular}{|l|c|c|}
\hline & Kraj & Zagranica \\
\hline Outsourcing & $\begin{array}{c}\text { Onshore } \\
\text { outsourcing }\end{array}$ & $\begin{array}{c}\text { Offshore } \\
\text { outsourcing }\end{array}$ \\
\hline $\begin{array}{l}\text { Wewnętrzne } \\
\text { świadczenie }\end{array}$ & $\begin{array}{c}\text { Wewnętrzne } \\
\text { świadczenie ustug }\end{array}$ & $\begin{array}{c}\text { Captive } \\
\text { offshoring }\end{array}$ \\
\hline
\end{tabular}

$\mathrm{Z}$ uwagi na to, że procesem offshoringu zainteresowały się firmy konsultingowe, wydając wiele publikacji na ten temat, należy tu przytoczyć definicje z raportu Deutsche Bank Research, którego autorzy opierając się na badaniach OECD i McKinseya sformułowali następujący podział ${ }^{4}$ (tabela).

Zgodnie z przedstawiona typologią offshoring $\mathrm{w}$ zależności od tego, czy jest świadczony przez jednostkę powiązaną kapitałowo, czy nie nosi nazwę w pierwszym przypadku Captive Offshoring, a w drugim Offshore Outsourcing.

Natomiast zgodnie z opinią Ricka Clicka i Thomasa Dueninga cały proces relokacji funkcji firmy nosi nazwę Business Proces Outsourcing (w skrócie BPO), który to w zależności od miejsca świadczenia dzieli się na trzy typy: offshore, nearshore i onshore ${ }^{5)}$.

Offshore BPO dotyczy relokacji funkcji firmy do daleko położonych krajów, charakteryzujących się przede wszystkim niskimi kosztami pracy. W przypadku firm amerykańskich wymieniane sa takie kraje, jak: Indie, Chiny, Filipiny, Rosja. Jednak stworzenie modelu biznesowego, w którym usługi te świadczone są w tych lokalizacjach przez spółkę powiązaną kapitałowo nosi już nazwę Offshore Insourcing.

Onshore BPO dotyczy wydzielenia określonych funkcji firmy i przekazania ich zewnętrznemu podmiotowi w kraju.

Nearshore BPO dotyczy relokacji funkcji firmy, ale do krajów pozostających na tym samym kontynencie; jest to związane $\mathrm{z}$ wyższymi kosztami wykorzystania miejscowych zasobów, ale i z mniejszym ryzykiem związanym z fizyczną bliskością i podobieństwem kulturowym. W przypadku firm amerykańskich jako lokalizacje wymieniane są takie kraje, jak Meksyk i Kanada.

Wprawdzie autorzy nie podają nazwy dla usług świadczonych w bliższych lokalizacjach przez podmioty powiązane kapitałowo, jednak na zasadzie analogii proces ten można nazwać Nearshore Insourcing.

Nieco inną definicję podają Marcia Robinson i Ravi Kalakota $^{6}$. Cały proces relokacji funkcji firmy określają jako Offshore Outsourcing, przy czym rozróżniają terminy offshoring i BPO (Business Process Outsourcing), wyjaśniając, że proces o nazwieoutsourcing dotyczy przekazania funkcji firmy do podmiotu nie powiązanego kapitałowo, natomiast offshoring dotyczy zarówno świadczenia usług przez podmiot nie powiązany, jak i powiązany. Autorzy wyróżniają także 
BPO - wydzielenie funkcji firmy nie będących funkcjami informatycznymi (np. kadry, płace, finanse, księgowość, przetwarzanie danych itp.) i ITO (Information Technology Outsourcing) dotyczący wydzielenia funkcji związanych z obsługą informatyczną (np. tzw. help desk, wsparcie techniczne).

Pojawiają się też próby tworzenia zupełnie nowego terminu dotyczacego optymalnej relokacji funkcji firmy, jak np. Offsourcing, słowo powstałe w wyniku połaczenia słów Offshoring i Outsourcing ${ }^{7)}$.

Należy zwrócić uwagę na samą nieostrość terminu nearshoring. Odnosi się on do przenoszenia funkcji firmy, po pierwsze, do krajów znajdujących się na tym samym kontynencie, a po drugie, nie będacych bardzo nisko kosztowymi lokalizacjami (np. w porównaniu z Indiami i Chinami), ale rekompensującymi to bliskością kulturową i wysoką jakością świadczonych usług. W przypadku firm amerykańskich jest to np. Kanada i Meksyk, a w przypadku firm europejskich np. Polska, Rumunia i Węgry.

Termin ten nie jest do końca zrozumiały, ponieważ w Polsce swoje centra wspólnych usług czy badań i rozwoju tworzą firmy amerykańskie (np. Philips, Motorola), czy koreańskie (np. Samsung). W przypadku tych firm Polska nie stanowi lokalizacji nearshoringowej, gdyż kraj ten mieści się na innym kontynencie, tak więc nie ma spełnionego kryterium „near”, nie stanowi też lokalizacjioffshoringowej, gdyż nie jest krajem o bardzo niskich kosztach. Interesujace jest też to, że np. dla firm koreańskich przeniesienie pewnych funkcji firmy do Indii czy Chin (wymienianych jako przykład lokalizacji offshoringowych) powinno być traktowane jako nearshoring ze względu na bliskość geograficzną i kulturową.

W przyszłości należy się spodziewać rozwoju definicji określających proces offshoringu i jego typy. Brak ugruntowanej typologii świadczy o nowości tego zjawiska, jak i szybkim jego rozwoju, dlatego też pojawiają się coraz to nowe, niekiedy sprzeczne terminy i definicje próbujące określić nowo zachodzące i jeszcze nie ustabilizowane procesy.

\section{Czynniki rozwoju offshoringu}

O ffshoring był już praktycznie stosowany od lat 80. ub. wieku, gdy takie firmy, jak Texas Instruments (1980) i Motorola (1981) otworzyły swoje pierwsze centra usługowe w Indiach. W kolejnych latach firmy te znajdowały coraz więcej naśladowców, aż w połowie lat 90. największe firmy komputerowe, jak Microsoft i SAP otworzyły w Indiach swoje centra rozwoju oprogramowania ${ }^{8}$. Rozwój zjawiska offshoringu począwszy od lat 90 . można powiązać z 6 głównymi czynnikami związanymi z rozwojem technologii, zmianami w organizacji firm oraz upowszechnieniem edukacji na wysokim poziomie. Są one przedstawione na rysunku.

\section{Upowszechnienie edukacji}

Wprawdzie Stany Zjednoczone i Europa Zachodnia wciąż dominują w poziomie jakości wyższego wykształcenia, jednak w krajach słabiej rozwiniętych tworzą się enklawy skupiające ośrodki badawcze i fir-

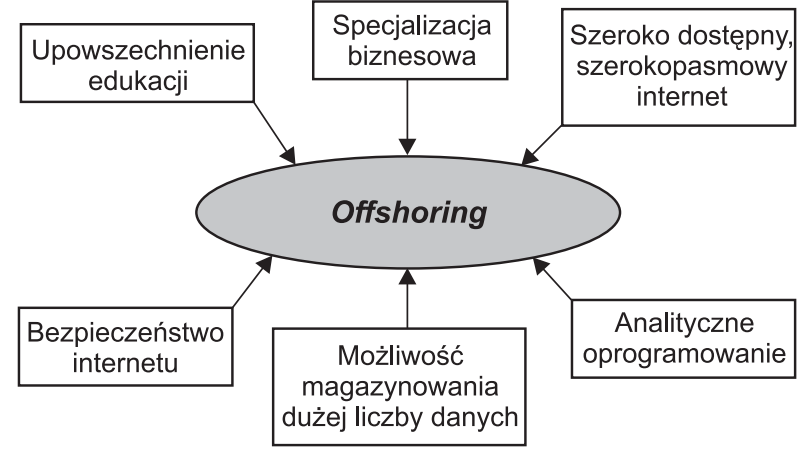

Rys. Czynniki rozwoju offshoringu

Źródło: opracowanie własne na podstawie: R.L. CLICK, T.N. DUENING, BPO - The Competitive Advantage, John Wiley \& Sons, New Jersey 2005.

my zatrudniające studentów niekiedy ze stopniem doktora uzyskanym w Harwardzie, Oxfordzie, MIT i innych prestiżowych uczelniach. Im więcej studentów po ukończonych zagranicznych studiach wraca do rodzinnych krajów, tym bardziej przyczynia się to do rozwoju wyższej edukacji na świecie. Należy także zauważyć, że USA pozostają w tyle za innymi krajami, szczególnie w liczbie studentów kończących studia matematyczne i techniczne. Powoduje to, że amerykańskie, a obecnie i europejskie firmy szukają talentów za granicą, aby móc skutecznie konkurować na rynku.

\section{Upowszechnienie szerokopasmowego internetu}

Szerokopasmowy internet odnosi się do przepustowości sieci osiągającej 2 megabity/sek. Taka pojemność pozwala na szybkie i niezakłócone przesyłanie danych. Szerokopasmowy internet zastępuje połączenia za pomocą łącza telefonicznego i umożliwia kontakt nawet pomiędzy firmami znajdujacymi sie w znacznej odległości (np. na innych kontynentach), dlatego też fizyczna lokalizacja przedsiębiorstw traci na znaczeniu.

\section{Możliwość magazynowania dużej liczby danych}

Komputeryzacja miejsc pracy spowodowała zastąpienie systemu gromadzenia danych opartego na papierowych wydrukach przez magazyn archiwizowany na nośnikach magnetycznych. W momencie integracji internetu z innymi technologiami procesów biznesowych, gromadzenie danych przestało być problemem. Firmy zauważyły, że gromadzenie danych w internetowych magazynach stało się konieczne i że taki magazyn jest nieograniczony jak sam internet. Zalety internetowego magazynowania danych, włączając w to wyrafinowany system ich wyszukiwania, doprowadziły do drastycznego spadku kosztów magazynowania oraz umożliwiły dostęp do nich z każdego miejsca na ziemi.

\section{Analityczne oprogramowanie}

Narzędzia, które pierwotnie zostały wymyślone, aby pomagać człowiekowi w pracy, obecnie w coraz 
większym stopniu są projektowane, aby wykonywać tę pracę za człowieka. Analityczne oprogramowanie wpłynęło na zmiany w strukturze zatrudnienia, projektowanie organizacji i produktywność. Mimo że wdrożenie analitycznego oprogramowania umożliwiło wyeliminowanie niektórych prac ludzkich, skierowało ono uwagę na jednostki, które potrafią posługiwać się tym wyrafinowanym komputerowym dorobkiem i „wyciągnąć” z niego wartość dodaną.

Oprogramowanie, które dostarcza dane w taki sposób, jak byłyby one przetworzone przez człowieka, pozwoliło na poszukiwanie niskokosztowej siły roboczej na takiej samej zasadzie, jak zrobił to wcześniej przemysł.

\section{Bezpieczeństwo internetu}

Bezpieczeństwo internetu odnosi się do możliwości przesyłania informacji i danych bez obawy o przeciek, szpiegostwo, czy całkowitą ich utratę. Sprawa podstawowa dla firm jest posiadanie pewności, że integralność danych przesyłanych przez internet będzie zachowana. W przeszłości wielu zarządzających firmami było przeciwnych dokonywaniu jakichkolwiek transakcji biznesowych przez internet, ze względu na bezpieczeństwo. Jednak przy obecnym zaangażowaniu technologicznym, większość osób zdecydowanie lepiej rozumie protokoły bezpieczeństwa dotyczące internetu. Dzięki temu przełomowemu wynalazkowi technologicznemu firmy mogą teraz pracować w obrębie „wirtualnych ścian” z takim samym poczuciem bezpieczeństwa. Systemy bezpieczeństwa zawierają obecnie: pełnomocnictwa do serwerów, hasła, autoryzacje, tzw. zapory ogniowe, certyfikaty i inne. Dzięki tym narzędziom firmy mogą bezpiecznie dzielić się swoimi zasobami w wirtualnym świecie. Dodatkowo wiele organizacji wdrożyło specjalne wewnętrzne polisy bezpieczeństwa, aby chronić najważniejsze dane. Pojawiły się także międzynarodowe certyfikaty świadczące o bezpieczeństwie internetowym. Są to: BS 7799, ISO 17799, HIPAA. Wszystkie wyżej wymienione procesy tworzą bardzo bezpieczną (chociaż wciąż niedoskonałą) infrastrukturę komunikacyjną. Należy sobie jednak zdawać sprawę, że wzrostowi bezpieczeństwa internetowego towarzyszy również wzrost liczby przypadków szpiegostwa internetowego czy przestępstw internetowych. Jednakże duża liczba różnorodnych zabezpieczeń skutecznie zniechęca weekendowych hakerów i bywa drogim i ryzykownym przedsięwzięciem dla wszystkich innych.

\section{Specjalizacja biznesowa}

Specjalizacja biznesowa znów stała się ważnym tematem w ciągu ostatnich dziesięcioleci. W swojej książce pt. Przewaga konkurencyjna jutra Prahalad i Hamel zwrócili uwagę na to, że firmy powinny się koncentrować na swojej działalności podstawowej core competency, jak również powinny rozwijać swoje portfele działalności podstawowej wokół swoich klientów ${ }^{9}$. Pomysł koncentracji na kluczowych kompetencjach jest logiczny i opiera się na założeniu, że przedsiębiorstwa nastawione na zysk powinny mieć w swoim obrębie tak mało niskoprzychodowych jednostek operacyjnych, jak to tylko możliwe. Jest bowiem wiele operacji, które dana firma przeprowadza, a które nie są bezpośrednio związane $\mathrm{z}$ generowaniem przez nią przychodów (np. księgowość, porady prawne, pensje, zasoby ludzkie i inne). Jeśli firma skoncentrowana jest na swojej „podstawowej działalności”, nie będzie zajmowała się kwestiami, które nie są bezpośrednio związane ze spełnieniem oczekiwań klientów i generowaniem przychodów. Ta zmiana w procesie myślenia menedżerów w związku z organizacją i funkcjami firmy jest głównym czynnikiem związanym z przemieszczaniem się operacji firmy.

\section{Podsumowanie}

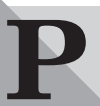

roces offshoringu, jak wspomniano wcześniej, nie jest zjawiskiem nowym, wcześniej do innych (zazwyczaj tańszych) lokalizacji przenoszono funkcje produkcyjne, a obecnie funkcje usługowe firm. Wpływ różnego rodzaju czynników, które wystąpiły w tym samym czasie, spowodował, że pionierzy znaleźli i wciąż znajdują licznych naśladowców. Z badań przeprowadzonych wspólnie przez firmę Roland Berger i UNCTAD na reprezentatywnej grupie największych 500 europejskich firm wynika, że $50 \%$ z nich planuje przeniesienie części swoich usług już w ciągu najbliższych kilku lat ${ }^{10)}$. Gdy coraz więcej przedsiębiorstw włączy się w ten proces, stanie się on standardem w zarządzaniu korporacjami międzynarodowymi i wtedy będą one poszukiwać nowego źródła przewagi konkurencyjnej.

Katarzyna Zakrzewska Studium doktoranckie SGH

\section{PRZYPISY}

1) Por. DEUTSCHE BANK RESEARCH, Offshoring: Globalisation Wave Reaches a Service Sector, $\mathrm{nr}$ 45, 27 września 2004, McKINSEY GLOBAL INSTITUTE, Offshoring: Is it a Win-Win Game?, sierpień 2003.

2) R. BERGER, UNCTAD 2004, Offshoring $w$ europejskim wydaniu, Warszawa, 1 lipca 2004, s. 2.

3) McKINSEY GLOBAL INSTITUTE, Offshoring: Is it a Win-Win Game?, sierpień 2003 s. 4.

4) DEUTSCHE BANK RESEARCH, Offshoring: Globalisation Wave Reaches a Service Sector, nr 45, 27 września 2004, www.db.com, s. 3.

5) R.L. CLICK, T.N. DUENING, $B P O$ - The Competitive Advantage, John Wiley \& Sons, New Jersey 2005, s. $20-23$.

6) M. ROBINSON i R. KALAKOTA, Offshore Outsourcing - Business Models ROI and Best Practices, E-business Strategies Inc. 2005, s. 4-5.

7) A. LOVVORN, B. KEDIA, S. LAHIRI, Defining Questions for Global Operations, „European Business Forum”, wydanie 9, jesień 2004, s. 43-46.

8) DEUTSCHE BANK RESEARCH, Offshoring: Globalisation Wave Reaches a Service Sector, nr 45, 27 września 2004, www.db.com, s. 8.

9) G. HAMEL i C.K. PRAHALAD, Przewaga konkurencyjna jutra, Business Press, Warszawa 1999.

10) R. BERGER, UNCTAD 2004, Offshoring $w$ europejskim wydaniu, Warszawa, 1 lipca 2004, s. 1. 